\title{
Predictors of long term outcomes of IgA nephropathy
}

\author{
U Kabir ${ }^{*}$, T Rahman, D Connaughton, P Conlon \\ From International Conference for Healthcare and Medical Students 2011 \\ Dublin, Ireland. 4-5 November 2011
}

\section{Introduction}

IgA Nephropathy (IgAN) was first described by Berger and Hinglais in 1968. The correlations between clinical as well as histopathological features on presentation and disease progression still remain unclear.

\section{Aim}

To identify the key predictors of long term renal outcomes in IgAN.

\section{Methods}

Two hundred patients with biopsy proven IgAN were selected and their clinical as well as histopathological data was analysed for progression to End-stage renal disease (ESRD).

\section{Results}

98 patients were used as the selected cohort. $21.5 \%$ of patients developed ESRD within 5 years and $28.8 \%$ within 10 years. Univariate studies showed that interstitial fibrosis, glomerulosclerosis, presence of fibrocellular crescents, proteinuria $(\mathrm{g} / 24 \mathrm{hrs})$ and raised serum creatinine levels at the time of biopsy were significant. ( $\mathrm{P}$ value of $<0.001$ and 95\% CI considered significant.) In the multifactorial analysis interstitial fibrosis and raised serum creatinine, lost their significance. (P value of $<0.05$ and $95 \% \mathrm{CI}$ considered significant.)

\section{Conclusions}

Combination of proteinuria, glomerulosclerosis and fibrocellular crescents may contribute to poor renal outcomes in patients with IgAN. Interstitial fibrosis and raised serum creatinine levels may have solitary effects on disease progression as well.

Royal College of Surgeons in Ireland, Ireland
Published: 9 July 2012

doi:10.1186/1753-6561-6-S4-P50

Cite this article as: Kabir et al:: Predictors of long term outcomes of IgA nephropathy. BMC Proceedings 2012 6(Suppl 4):P50.
Submit your next manuscript to BioMed Central and take full advantage of:

- Convenient online submission

- Thorough peer review

- No space constraints or color figure charges

- Immediate publication on acceptance

- Inclusion in PubMed, CAS, Scopus and Google Scholar

- Research which is freely available for redistribution

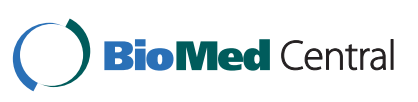

() 2012 Kabir et al; licensee BioMed Central Ltd. This is an Open Access article distributed under the terms of the Creative Commons Attribution License (http://creativecommons.org/licenses/by/2.0), which permits unrestricted use, distribution, and reproduction in any medium, provided the original work is properly cited. 